\title{
Yield Gap Analysis of Soybean through Front Line Demonstrations in Pratapgarh: A Tribal District of Rajasthan, India
}

\author{
Yogesh Kanojia*, Harish Chandra Singh and R.K. Damor
}

Krishi Vigyan Kendra, Pratapgarh, Rajasthan, India

*Corresponding author

\section{A B S T R A C T}

\begin{tabular}{|c|c|}
\hline \\
\hline Keywords & \multirow{4}{*}{$\begin{array}{l}\text { Front line demonstration is an effective and appropriate tool to demonstrate recommended } \\
\text { technologies among the farmers. Krishi Vigyan Kendra, Pratapgarh (Rajasthan) conducted } \\
482 \text { demonstrations on soybean from } 2013 \text { to } 2017 \text { in eight adopted villages. The critical } \\
\text { inputs were identified in existing production technology through farmers meeting and } \\
\text { group discussion with the farmers. The five years data revealed that an average yield of } \\
\text { demonstration plot was obtained } 15.16 \mathrm{q} / \mathrm{ha} \text { over local check (13.06 q/ha) with an } \\
\text { additional yield of } 2.1 \mathrm{q} / \mathrm{ha} \text { and average soybean productivity increased by } 16.56 \% \text {. The } \\
\text { average technology gap and technology index were observed } 4.84 \mathrm{q} / \mathrm{ha} \text { and } 24.20 \% \\
\text { respectively. }\end{array}$} \\
\hline $\begin{array}{l}\text { Front line } \\
\text { demonstration, } \\
\text { Technology gap, } \\
\text { Technology index }\end{array}$ & \\
\hline Artic & \\
\hline $\begin{array}{l}\text { Accepted: } \\
\text { 10 March } 2019 \\
\text { Available Online: } \\
10 \text { April } 2019\end{array}$ & \\
\hline
\end{tabular}

\section{Introduction}

India is the fourth largest producer of oilseed and fifth largest producer of soybean in the world. Now a days, soybean is major oil seed crop of India. In India share of soybean in total oilseed is about 25\%. The continuous increase in import of oilseed and oil is a matter of great concern in Indian oilseed scenario. In India during the year 2017-18 total area under soybean was 17.42 million hectare and production was 20.68 million tonnes with the productivity of $1187 \mathrm{~kg}$ per hectare. In Pratapgarh district area under soybean crop is increasing every year. The area under soybean cultivation in state was 886487 hectares and the production was
1069830 tonnes with the productivity of 1207 $\mathrm{kg} / \mathrm{ha}$ (2017-18). Soybean crop having highest acreage in Kharif season in the district but large yield gap exist between potential yield and yield under real farming situations. Pratapgarh district is situated in southern part of Rajasthan. About $70 \%$ population of the district is tribal and economic condition of farmers is also limiting factor for soybean cultivation. Soybean is major kharif crop of the district. The area under crop in district is 129545 hectare and production is 154689 tonnes with the productivity of $1194 \mathrm{~kg} / \mathrm{ha}$ (2017-18). The poor productivity is because of resource poor farmers are very reluctant towards scientific management of crops. 


\section{Materials and Methods}

The study was carried by the KVK, Pratapgarh during Kharif season 2013 to 2017 (five consecutive years) at the farmers field of eight adopted villages (Jhakar, Devgarh, Motikhedi, Lalpura, Samli Pathar, Mota Mayanga, Jawahar Nagar \& Mandkalan) of Pratapgarh district. During this five year of study an area of 192.5 ha was covered with plot size 0.4 ha under front line Demonstration with active participation of 482 Farmers. Before conducting the FLDs, a list of farmers was prepared from group meeting and specific skill training was imparted to the selected farmers regarding different aspect of cultivation (Venkattakuma et al., 2010). The difference between the demonstration package and existing farmer's practices are given in table 1 . The soil type of area under study was clay to clay loam in texture with $\mathrm{pH}$. range 7.0 to 7.5 . The available nitrogen phosphorus and potassium varied between 128- 267, 4-18 and 365-672 $\mathrm{kg} / \mathrm{ha}$ respectively. However, the soil is deficient in sulphur and zinc status.

In the demonstration plots, use of quality seed of improved varieties, seed treatment, timely sowing, timely weeding, need based pesticide as well as balance fertilization (Use of micro nutrient zinc and sulphur) were emphasized and comparison has been made with the existing practices of farmers. The necessary steps for selection of sites and farmers, layout of demonstration etc were followed as suggested by Choudhary (1999).The traditional practices were mentioned in case of local checks. The data output were collected from both FLD plots as well as control plots and finally the per cent increase yield, Extension Gap, Technology Gap, Technology Index along with the benefit cost ratio were worked out (Samui et al., 2000) as given below.
Percent increase yield $=($ Demonstration yield - farmers yield)/ farmers yield X 100

Technology Gap = Potential yieldDemonstration Yield

Extension Gap $=$ Demonstration YieldFarmer Yield

Technology Index = (Technology Gap/ Potential Yield) x 100

\section{Results and Discussion}

The data of table 2 revealed that the yield of soybean fluctuated successively over the year in demonstration plots. The maximum yield was recorded (16.40 q/ha) during 2013 and minimum yield was recorded $13.80 \mathrm{q} / \mathrm{ha}$ in year 2016. The average yield of five years was recorded $15.16 \mathrm{q} / \mathrm{ha}$ over local check $13.06 \mathrm{q} / \mathrm{ha}$. The increase in percentage yield was ranged from 11.29 to $25.89 \%$ during five year of study. On average basis 16.56 percentage increase in yield was recorded. The results are in conformity with the finding of Tomar et al., (2003), Tiwari and Saxena (2001) Tiwari et al., (2003) and Katare et al., (2011). The Extension gap was also decreased and it was ranged from 1.2 to $2.9 \mathrm{q} / \mathrm{ha}$. During the period of study, it was emphasized the need to educate the farmers through various means for adoption of improved agricultural production technology to reduce the trends of wide extension gap. The trend of Technology gap (ranging between 3.6 to $6.2 \mathrm{q} / \mathrm{ha}$ ) reflects the farmers cooperation in carrying out such demonstration with encouraging results in subsequent years. The technology observed may be attributing to the dissimilarity in soil fertility status and uncertainty of weather condition. Similar findings were recorded by Mitra et al., (2010). The technology index showed that the feasibility of evolved technology at the farmers field. 
Table.1 Comparison between demonstration package and existing practices under soybean FLD

\begin{tabular}{|l|l|l|l|}
\hline S. No. & Particulars & Demonstrations & Farmers practice \\
\hline $\mathbf{1}$ & Farming Situation & Rainfed & Rainfed \\
\hline $\mathbf{2}$ & Variety & JS- 9560 & JS-335 \\
\hline $\mathbf{3}$ & Time of sowing & 25 June-10 July & 25 June-15 July \\
\hline $\mathbf{4}$ & Method of sowing & Line sowing & Line sowing \\
\hline $\mathbf{5}$ & Seed Treatment & Carbendazim $2 \mathrm{gm} / \mathrm{kg}$ seed & No Seed treatment \\
\hline $\mathbf{6}$ & Seed rate & $80 \mathrm{~kg} / \mathrm{ha}$ & $120-150 \mathrm{~kg} / \mathrm{ha}$ \\
\hline $\mathbf{7}$ & Fertilizer dose & As per soil test value & $50 \mathrm{~kg}$ DAP per acre \\
\hline $\mathbf{8}$ & Plant Protection & $\begin{array}{l}\text { Quinalphos for beetle } \\
\text { Profenofos for caterpillars and } \\
\text { Imidachloprid for white fly }\end{array}$ & Not specific \\
\hline $\mathbf{9}$ & Weed Management & Imyzathyper 75 ml ai/ha & Manual/ mechanical \\
\hline
\end{tabular}

Table.2 Productivity, extension gap, technology gap and technology index of soybean as grown under CFLD's and existing package of practices

\begin{tabular}{|c|c|c|c|c|c|c|c|c|}
\hline \multirow[t]{2}{*}{ Year } & \multirow{2}{*}{$\begin{array}{c}\text { Area } \\
\text { (ha) }\end{array}$} & \multirow{2}{*}{$\begin{array}{c}\text { No. } \\
\text { of } \\
\text { Demo }\end{array}$} & \multicolumn{2}{|c|}{ Yield (q/ha) } & \multirow{2}{*}{$\begin{array}{c}\text { Increase } \\
\text { in yield } \\
(\%)\end{array}$} & \multirow{2}{*}{$\begin{array}{c}\text { Extension } \\
\text { gap } \\
(\mathbf{q} / \mathbf{h a})\end{array}$} & \multirow{2}{*}{$\begin{array}{l}\text { Technology } \\
\text { gap (q/ha) }\end{array}$} & \multirow{2}{*}{$\begin{array}{l}\text { Technology } \\
\text { Index }(\%)\end{array}$} \\
\hline & & & Demo & Farmer & & & & \\
\hline 2013 & 32.5 & 82 & 16.4 & 15.2 & 7.89 & 1.2 & 3.6 & 18.00 \\
\hline 2014 & 40 & 100 & 15.6 & 13.2 & 18.18 & 2.4 & 4.4 & 22.00 \\
\hline 2015 & 30 & 75 & 14.1 & 11.2 & 25.89 & 2.9 & 5.9 & 29.50 \\
\hline 2016 & 40 & 100 & 13.8 & 12.4 & 11.29 & 1.4 & 6.2 & 31.00 \\
\hline 2017 & 50 & 125 & 15.9 & 13.3 & 19.55 & 2.6 & 4.1 & 20.50 \\
\hline Average & 38.50 & 96 & 15.16 & 13.06 & 16.56 & 2.10 & 4.84 & 24.20 \\
\hline
\end{tabular}

Table.3 Gross Return, Net Return, Gross cost Cultivation and BC Ratio of soybean as grown under FLDS and existing package of practices

\begin{tabular}{|c|c|c|c|c|c|c|c|c|}
\hline \multirow{2}{*}{ Year } & \multicolumn{2}{c|}{$\begin{array}{c}\text { Cost of Cultivation } \\
(\text { Rs) }\end{array}$} & \multicolumn{2}{c|}{$\begin{array}{c}\text { Gross Return } \\
(\mathbf{R s})\end{array}$} & \multicolumn{2}{c|}{ Net Return (Rs) } & \multicolumn{2}{c|}{ B:C Ratio } \\
\cline { 2 - 9 } & Demo & Farmer & Demo & Farmer & Demo & Farmer & Demo & Farmer \\
\hline $\mathbf{2 0 1 3}$ & 19735 & 19250 & 59040 & 53200 & 39305 & 33950 & 1.99 & 1.76 \\
\hline $\mathbf{2 0 1 4}$ & 22400 & 20200 & 46800 & 38280 & 24400 & 18080 & 1.09 & 0.90 \\
\hline $\mathbf{2 0 1 5}$ & 19600 & 17300 & 52875 & 42000 & 33275 & 24700 & 1.70 & 1.43 \\
\hline $\mathbf{2 0 1 6}$ & 23250 & 21120 & 41400 & 37200 & 18150 & 16080 & 1.78 & 1.76 \\
\hline $\mathbf{2 0 1 7}$ & 23834 & 20580 & 44520 & 37240 & 20686 & 16660 & 1.87 & 1.81 \\
\hline Average & $\mathbf{2 1 7 6 4}$ & $\mathbf{1 9 6 9 0}$ & $\mathbf{4 8 9 2 7}$ & $\mathbf{4 1 5 8 4}$ & $\mathbf{2 7 1 6 3}$ & $\mathbf{2 1 8 9 4}$ & $\mathbf{1 . 6 9}$ & $\mathbf{1 . 5 3}$ \\
\hline
\end{tabular}


The lower value of technology index the more is the feasibility of technology. As fluctuation in technology index (Ranging between 18 31 ) during the study passed in certain region may be attributed to the dissimilarity in soil fertility, status, uncertainty of weather condition. The results clearly indicate the positive effects of FLD over the existing practices towards enhancing the yield of soybean in the tribal district Pratapgarh. Benefit cost ratio was recorded to be higher under demonstration against control during all the years of study (Table 3).

In the light of above findings it can be concluded that use of recommended scientific packages and practices of soybean cultivation can reduce the technology gap to a considerable extent thus leading to increased productivity of soybean of tribal farmers of the district. Moreover, extension agencies of the district need to provide proper technical support to the farmers through different education and extension methods to reduce the extension gap for better soybean production in Tribal district Pratapgarh.

\section{References}

Agricultural Statistics, Jaipur, Rajasthan (Fourth estimate, 2017-18).

Annual Report, Deptt. of Agriculture, Cooperation \& Farmers Welfare, New Delhi (2017-18).

Choudhary, B.N. (1999) Krishi Vigyan Kendra- A guide for KVK managers, Division of Agricultural Extension,
ICAR pp. 73-78.

Katare, Subhash, Pandey, S.K. and Mustafa, Mohd (2011). Yield gap analysis of Rapeseed mustard through front line demonstration. Agric. update, 6(2): 57.

Mitra Biplab, and Samajdar, T.(2010)- Yield gap analysis of rapeseed mustard through front line demonstration Agric. Exten. Review, April-June pp,16-17.

Samui, S.K., Mitra,S., Roy, D.K. Mandal, A.K. and Saha D.(2000), Evaluation of front line demonstration on groundnut. J. Indian Soc. Coastal Agric. Res. 18(2) 180-183.

Tiwari, K.B. and Saxena, A.(2001) Economic analysis of FLD of oilseed in chhindwara. Bhartiya Krishi Anusandhan Patrika 16(3\&4) 185189.

Tiwari, R.B. Singh, Vinay and Parihar, Pushpa (2003), Role of FLD in transfer of gram production technology. Maharashtra J. Ext. Edu,22(1) 19.

Tomer, L.S. Sharma, B.P. and Joshi K. (2003) Impact of Front line Demonstration of soybean in transfer of improved technology J. Ext. Edu 22(1), 139.

Venkattakumar, R. Ramana Rao, S.V. Padmaiah, M. and Madhuri P.(2010) Production constraints and information needs of grower in Andhra Pradesh Agric. Extn. Review (Apr-June) pp 21-24.

\section{How to cite this article:}

Yogesh Kanojia, Harish Chandra Singh and Damor, R.K. 2019. Yield Gap Analysis of Soybean through Front Line Demonstrations in Pratapgarh: A Tribal District of Rajasthan, India. Int.J.Curr.Microbiol.App.Sci. 8(04): 1020-1023. doi: https://doi.org/10.20546/ijcmas.2019.804.118 